\title{
NIERÓWNOŚCI SPOŁECZNO-EKONOMICZNE W ŚWIETLE TEORII SEGMENTACJI RYNKU PRACY
}

\section{WPROWADZENIE}

W ramach teorii segmentacji rynku pracy skonstruowano kilka hipotez wyjaśniających istnienie nierówności w sferze pracy zawodowej. Hipotezy te wyjaśniają sprzeczności między modelowymi założeniami neoklasycznej teorii rynku pracy a nierównościami w zatrudnieniu i w płacach występującymi między różnymi grupami społecznymi. W ramach nurtu teorii segmentacji rynku pracy wyróżnić można kilka wariantów teorii, które różnią się między sobą liczbą zdefiniowanych segmentów rynku, silniejszym lub słabszym akcentowaniem związku podziału rynku pracy ze struktura całej gospodarki, wyjaśnianiem genezy i utrzymywania się podziału rynku pracy.

Celem artykułu jest próba wyjaśnienia istnienia nierówności między grupami społecznymi na rynku pracy na podstawie teorii segmentacji i wybranych teorii pokrewnych opartych na segmentacji oraz określenie determinant tych nierówności.

\section{SEGMENTACJA STATYSTYCZNA}

Segmentacja statystyczna rynku pracy polega na podziale tego rynku według widocznych, łatwych do określenia cech pracowników. Kryteriami stratyfikacyjnymi podziału populacji na grupy moga być: płeć, rasa, narodowość, wiek, stan cywilny, niepełnosprawność, orientacja seksualna itp.

W momencie zatrudniania pracownika trudno jest określić, czy kandydat ma cechy pożądane przez pracodawcę. Przyjęcie nieodpowiedniego pracownika i późniejsze jego zwolnienie pociąga za sobą koszty dla pracodawcy. Pracodawcy stosują więc statystyczną segmentację, wykorzystując widoczne wyróżniki (takie jak płeć, wiek, narodowość, rasa) jako przybliżone wskaźniki posiadania pożądanych cech. Przypisują poszczególnym grupom społecznym cechy, które niekoniecznie są im właściwe lub jednostkom do nich przypisanym, a często sa oparte na stereotypowym odbiorze danej grupy. Osoby, których powierzchowne cechy wydają się w odczuciu pracodawców statystycznie skorelowane $\mathrm{z}$ niepożądanymi zachowaniami, są w ten sposób odrzucane.

Cechy przypisywane (a niekoniecznie prawdziwe) grupom dyskryminowanym to mniejsze zainteresowanie praca zawodową, większe nastawienie na życie rodzinne niż na pracę, niższe aspiracje dotyczące zarobków i awansów, 
mniejsze zainteresowanie szkoleniami zawodowymi, mniejsze uprawnienia do pewności zatrudnienia i wyższych zarobków, mniejsze potrzeby usprawiedliwiające niższe zarobki czy odmienność społeczna (stygmatyzacja).

Niezgodność cech przypisywanych grupom dyskryminowanym z wymaganiami stawianymi kandydatom prowadzi do statystycznej dyskryminacji. $\mathrm{W}$ rezultacie osoby $\mathrm{z}$ grup dyskryminowanych otrzymuja prace $\mathrm{z}$ jednej strony niżej płatne, a $\mathrm{z}$ drugiej - w ogóle moga nie być zatrudniane na pewnych stanowiskach pracy. Statystyczna segmentacja prowadzi więc do różnic w zarobkach na niekorzyść wybranych grup społecznych - uniemożliwia im dostęp do lepiej płatnych miejsc pracy oraz zajmowanie pewnych, ,lepszych” stanowisk pracy.

Determinantami nierówności w sferze pracy zawodowej według tej teorii sa segmentacja rynku pracy według wyróżników charakterystycznych dla poszczególnych grup społecznych, przypisywanie poszczególnym grupom społecznym określonych cech i zasady selekcji pracowników do pracy.

\section{KONCEPCJA RYNKÓW WEWNĘTRZNYCH I ZEWNĘTRZNYCH}

Według koncepcji rynków zewnętrznych i wewnętrznych rynek pracy składa się z dwóch odmiennych, oddzielonych od siebie rynków - rynków zewnętrznych (ZRP) i wewnętrznych (WRP). Zewnętrzny rynek pracy obejmuje obszary znajdujące się poza rynkami wewnętrznymi. Stanowi pewnego rodzaju „,resztę”, istniejącą wszędzie tam, gdzie nie rozwinęły się rynki wewnętrzne ${ }^{1}$.

Wewnętrzne rynki pracy charakteryzuja się stabilnością załóg (długookresowe stosunki pracy regulowane systemowo), ściśle określonymi regułami awansowania, ograniczeniem dostępu nowych pracowników, dla których przeznaczone są tylko stanowiska na dole drabiny awansowania, regulowaniem płac przez trwałe normy i procedury, manewrowaniem czasem i podziałem pracy na poszczególne stanowiska, organizacją kształcenia zawodowego.

Według P. Doeringera i M. Piore'a istnieja trzy podstawowe czynniki prowadzące do powstania WRP:

- kwalifikacje specyficzne dla danego przedsiębiorstwa i niedające się przenieść do innego;

- szkolenie lub przyuczenie na stanowisku pracy;

- obyczaje, które dotyczą relacji płac i rozmieszczenia pracowników na stanowiskach $^{2}$.

Specyficzne dla firmy kwalifikacje wymagają szkoleń na stanowisku pracy. Pracodawca dąży do tego, aby jego pracownicy zdobyli takie specyficzne kwalifikacje. Inwestuje więc $\mathrm{w}$ ich szkolenie, a następnie dąży do stabilności załogi, by uzyskać korzyści z tych inwestycji i nie ponosić dodatkowych kosztów związanych z przyjmowaniem do pracy coraz to nowych pracowników. W celu

\footnotetext{
${ }^{1}$ E. Kryńska, Teoria i praktyka segmentacji rynku pracy - częśc I, „Rynek Pracy” 1999, nr 2 (86), s. $16-17$.

${ }^{2}$ P. Doeringer, M. Piore, Internal Labor Markets and Manpower Analysis, D.C. Heath, Lexington, Mass., 1971, s. 20.
} 
ograniczenia kosztów fluktuacji zmniejsza płynność załóg przez dawanie pewności zatrudnienia i wyższych płac. Prowadzi to do stałości i ciąłości zatrudnienia. Pracownicy zaczynają tworzyć obyczaje oparte na powtarzalnych praktykach, które z czasem stają się quasi-moralnymi regułami.

Jeżeli powstaje nowy WRP na poprzednio konkurencyjnym rynku pracy, to część miejsc pracy i pracowników wycofuje się z ogólnej konkurencji. Przez takie działanie menedżerowie próbuja utrzymać swoją pozycję na rynku pracy, a pracownicy - stabilność zatrudnienia. Pracownicy dążą również do wyraźnie określonej hierarchii stanowisk i do uzależnienia awansu od stażu pracy w firmie. Nowych pracowników przyjmuje się tylko na najniższe stanowiska, które stanowią wejścia z zewnętrznego rynku pracy ${ }^{3}$.

Osoby pracujące na rynkach wewnętrznych są niejako oddzielone od osób pozostających na rynku zewnętrznym. Nie współzawodniczą z nimi o pracę. Konkurencja dokonuje się na każdym z rynków osobno. Oczywiście oba typy rynków nie są w pełni izolowane. Jednak dostęp do rynku wewnętrznego jest ograniczony, zwłaszcza do miejsc pracy stojących wysoko w hierarchii zakładowej.

Pracownicy zatrudnieni na WRP maja zapewniona pewność zatrudnienia, płac, dodatkowe świadczenia oraz awans, zwykle związany ze stażem pracy. Na tym polega ich uprzywilejowanie $\mathrm{w}$ porównaniu $\mathrm{z}$ zatrudnionymi na zewnętrznym, wolnokonkurencyjnym rynku pracy, na którym pewność pracy oraz możliwości awansu są dużo mniejsze oraz zarobki są relatywnie niższe.

Zakładowe wewnętrzne rynki pracy nie sa jednorodne. Proces segmentacji tych rynków polega na podziale ogółu pracowników na część zasadnicza i marginesową. Istnienie dwóch obszarów zakładowego rynku pracy jest sposobem rozwiazywania problemów dostosowania zatrudnienia do zmieniającego się zapotrzebowania na określoną wielkość produkcji ${ }^{4}$.

Część zasadnicza załogi zajmuje „lepsze” miejsca pracy, a ,gorsze” sa przeznaczone dla części marginesowej załogi. Miejsca pracy dzieli się na „lepsze” i „gorsze” według następujących kryteriów:

1) status stanowiska pracy, czyli usytuowanie danego miejsca pracy w hierarchii przedsiębiorstwa,

2) wysokość wynagrodzenia,

3) szanse awansu,

4) narażenie na ryzyko utraty miejsca pracy ${ }^{5}$.

Część zasadnicza pracowników można podzielić na segment górny (niezależny) i segment dolny (podporządkowany). Segment górny zawiera miejsca pracy wymagające inicjatywy, twórczej postawy w życiu zawodowym, a segment dolny obejmuje miejsca pracy wykonawczej, gdzie przede wszystkim wymaga się wysokiej dyscypliny pracy oraz niezawodności ${ }^{6}$.

${ }^{3}$ R. Loverige, A. L. Mok, Theories of Labour Market Segmentation. A Critique, Martinus Nijhof, Hague-Boston-London 1979, s. 60-64.

${ }^{4}$ Marginesowa część załogi wewnętrznych rynków pracy oraz załogi zewnętrznych rynków pracy stanowią tzw. zderzak koniunkturalny. Pracownicy ci są zwalniani w wypadku wahań popytu rynkowego.

${ }^{5}$ E. Kryńska, Teoria i praktyka segmentacji rynku pracy - część I, s. 18-20.

${ }^{6}$ E. Kryńska, Teoria i praktyka segmentacji rynku pracy - część II, „Rynek Pracy” 1999, nr 3 (87), s. 37. 
Ta teoria ukazuje determinanty nierówności na rynku pracy i tłumaczy jednocześnie gorszą pozycję wybranych grup społecznych w sferze pracy zawodowej. Pracodawcy na WRP oczekuja ciagłości zatrudnienia, przez co spychają wybrane grupy społeczne do części marginesowej lub w ogóle ich nie zatrudniaja. Natomiast firmy działające na zewnętrznym, konkurencyjnym rynku pracy, nie stosuja tak nowoczesnej, skomplikowanej technologii ani takiej organizacji pracy, jaka cechuje WRP, i dlatego nie wymagaja od pracowników ciągłości pracy, ale też nie dają im pewności zatrudnienia.

Determinantami nierówności na rynku pracy w koncepcji rynków wewnętrznych i zewnętrznych są z jednej strony segmentacja tego rynku, zasady selekcji kandydatów do pracy oraz interesy pracodawców dotyczące szkoleń pracowników, a z drugiej - nieciaggłość zatrudnienia oraz zróżnicowane role społeczne przypisywane różnym grupom społecznym.

\section{KONCEPCJA DUALNEGO RYNKU PRACY}

Teorie dualnego (dwojakiego) rynku pracy ${ }^{7}$ powstały w USA jako wyjaśnienie biedy pracowników mieszkających w murzyńskich gettach wielkich metropolii ${ }^{8}$, która to bieda jest konsekwencją zatrudniania ich na stanowiskach poniżej ich możliwości. Później teorie rozszerzono na inne grupy dyskryminowane na rynku pracy. Teorie te wyjaśniają przede wszystkim sytuację kategorii upośledzonych na rynku pracy przez samą jego strukturę ${ }^{9}$. Zasadnicze tezy tych teorii są następujace ${ }^{10}$ :

1) rynek pracy dzieli się na dwa segmenty: pierwszorzędny (primary) i drugorzędny (secondary) ${ }^{11}$;

2) zatrudnienie i płace są odmiennie determinowane $\mathrm{w}$ każdym $\mathrm{z}$ tych dwóch segmentów;

3) mobilność między segmentami jest ograniczona. Pracownicy drugorzędnego segmentu mają utrudnioną możliwość przejścia do pierwszorzędnego;

4) w drugorzędnym segmencie możliwości pracowników są niewykorzystane. Pracownicy nie podnoszą swoich kwalifikacji z powodu braku szkoleń w zakładach pracy.

${ }^{7}$ Koncepcję dualnego rynku pracy wprowadził, jako konstrukcję teoretyczną, M. Piore w 1969 r. Sprecyzowana została w pracach P. Doeringera i M. Piore'a w 1971 r. - zob. M. Piore, The Dual Labor Market. Theory and Applications, w: R. Barringer, S. H. Beer, The State and the Poor, Winthrop, Cambridge, Mass., 1970; P. Doeringer, M. Piore, op. cit.

${ }^{8}$ D. M. Gordon, Theories of Poverity and Underemployment. Orthodox, Radical and Dual Labor Market Perspectives, D.C. Heath, Lexington, Mass., 1974, s. 43.

${ }^{9}$ R. Hodson i R. Kaufman, analizując dualistyczny model gospodarki i rynku pracy, proponuja wyróżnienie czterech elementów teorii (zob. R. Hudson, R. L. Kaufman, Economic Dualism. A Critical Rewiew, „American Sociological Rewiew” 47, 1982, s. 727-739): 1) organizacja gospodarki kapitalistycznej i jej podział na dwa sektory; 2) organizacja siły roboczej, czyli podział rynku pracy na dwa segmenty i bariery w ruchliwości między nimi; 3) sytuacja pracowników wynikająca z uczestnictwa w segmencie centralnym albo peryferyjnym; 4) społeczny podział siły roboczej według płci, rasy i przynależności etnicznej.

${ }^{10}$ R. Loverige, A. L. Mok, op. cit., s. 47.

${ }^{11}$ Niektórzy autorzy dzielą segment pierwszorzędny na wyższy i niższy poziom (upper i lower tier) zależnie od autonomii pracy i zakresu władzy, np. P. Osterman, An Empirical Study of Labor Market Segmentation, ,Industrial and Labor Relations Rewiew” 28, 1975, s. 508-523. 
Segment pierwszorzędny charakteryzuje się miejscami pracy dającymi wysokie płace, dobre warunki pracy oraz możliwości awansu. W segmencie drugorzędnym miejsca pracy charakteryzują się gorszymi płacami, gorszymi warunkami pracy, mniejszymi szansami awansu, brakiem pewności pracy i wysoką fluktuacja pracowników ${ }^{12}$. Bezrobocie w tym segmencie rynku jest większe, gdyż stanowiska pracy są często likwidowane przez pracodawców albo sami pracownicy porzucają nieatrakcyjną i niedającą widoków na awans pracę. Zasadniczy podział na rynku pracy przebiega więc nie między wykwalifikowanymi i niewykwalifikowanymi pracownikami, ale między „dobrymi” i ,złymi” miejscami pracy ${ }^{13}$.

Kandydatom do pracy w pierwszorzędnym segmencie stawia się określone wymagania, których członkowie dyskryminowanych grup rzeczywiście lub pozornie nie moga spełnić. Te kategorie pracowników najczęściej zaczynaja karierę zawodową w drugorzędnym segmencie ze względu na większą łatwość uzyskania pracy. Przejście do segmentu pierwszorzędnego $\mathrm{z}$ segmentu drugorzędnego jest ogromnie utrudnione. Spowodowane jest to bądź przekonaniem o niestałości pracowników, bądź przekonaniem o nabieraniu złych nawyków w sektorze drugorzędnym. Historie zatrudnienia osób pracujących w sektorze drugorzędnym wykazują częste zmiany pracodawcy spowodowane likwidacja miejsc pracy lub rezygnacja $\mathrm{z}$ niezadowalajacych miejsc pracy, co następnie wykorzystuje się jako dowód, że nie spełniają oni podstawowego wymagania, czyli ciągłości pracy, które stawia się poszukującym pracy w pierwszorzędnym segmencie. Powstaje więc błędne koło, z którego nie ma wyjścia.

Nabieranie złych nawyków wynika ze sprzężenia między drugorzędnymi miejscami pracy a drugorzędnymi pracownikami. Te złe nawyki to np. nierzetelna praca czy porzucanie pracy. Powierzchowne cechy łączą się w przekonaniu pracodawców z takimi szkodliwymi nawykami ,drugorzędnych” pracowników. To przekonanie powoduje, że osoby z dyskryminowanych grup nie sa dopuszczane do „lepszych” miejsc pracy.

Zdaniem R. D. Barrona i G. M. Norrisa prawdopodobieństwo przynależności do kategorii drugorzędnych pracowników wzrasta, gdy można im przypisać pięć cech. Sa to:

1) łatwość zwolnienia,

2) wyraźnie widoczna odmienność społeczna,

3) mniejsze zainteresowanie uczestniczeniem w szkoleniu zawodowym $\mathrm{w}$ miejscu pracy,

4) łatwiejsze godzenie się na niskie zarobki,

5) brak solidarności ${ }^{14}$.

Wzrost ogólnej liczby zatrudnionych dokonuje się przez napływ pracowników ,,drugorzędnych”. Wobec tego coraz więcej pracodawców organizuje pracę i produkcję tak, by fluktuacja załogi nie podnosiła im kosztów.

${ }^{12}$ M. J. Piore, Notes for Theory of Labor Market Stratification, w: R. C. Edwards, M. Reich, D. M. Gordon, Labor Market Segmentation, D.C. Heath, Lexington, Mass., 1975, s. 126.

${ }^{13}$ A. L. Kallenberg, K. Sorensen, The Sociology of Labor Markets, „Annual Review of Sociology” 1979, nr 5, s. 351-379.

${ }^{14}$ R. D. Barron, G. M. Norris, Sexual Division and the Dual Labour Market, w: D. L. Barker, S. Allen Dependence and Exploitation in Work and Marriage, Longman, London-New York 1976, s. 125-148. 
Osoby z grup dyskryminowanych przeważają w sektorze drugorzędnym. To tłumaczy ich niższe płace oraz mniejsze możliwości awansowania. Poza tym pracując $\mathrm{w}$ drugorzędnym segmencie rynku, mają ograniczony dostęp do szkoleń w miejscu pracy i do świadczeń firmy na rzecz pracowników.

Według niektórych autorów granica między segmentami przebiega między firmami. Inni autorzy twierdzą natomiast, że granica ta przebiega również wewnątrz firm, gdyż wielkie firmy zatrudniają drugorzędnych pracowników pośrednio przez subkontrakty z małymi firmami z sektora konkurencyjnego albo zatrudniają ich bezpośrednio jako pracujących dorywczo lub w niepełnym wymiarze czasu pracy. Jeszcze inni dowodza, że podział rynku pracy na segmenty może przecinać zarówno firmy, jak i branże przemysłu i sektory gospodarki ${ }^{15}$.

Determinantami nierówności na rynku pracy w koncepcji dualnego rynku pracy są z jednej strony segmentacja rynku pracy, zasady selekcji kandydatów do pracy oraz interesy pracodawców dotyczące szkoleń pracowników, a z drugiej - faktyczne lub pozorne role społeczne i związana z tym nieciagłość zatrudnienia przypisywane różnym grupom społecznym oraz złe nawyki nabierane w drugorzędnych miejscach pracy.

\section{KONCEPCJA GOSPODARKI DUALNEJ}

Dwojaki rynek pracy wiąże się z dwojaką gospodarką, tj. z podziałem gospodarki na dwa sektory:

1) sektor centralny, zwany także kluczowym, monopolistycznym lub skoncentrowanym;

2) sektor peryferyjny, zwany również konkurencyjnym lub nieskoncentrowanym.

Sektor centralny składa się z wielkich, wpływowych, zbiurokratyzowanych korporacji. Kontroluja one dostawy surowców i sprzedaż towarów (pionowa integracja), działaja w wielu branżach i krajach. Stosuja nowoczesne, zaawansowane technologicznie systemy produkcji i sprzedaży. Natomiast sektor peryferyjny składa się $\mathrm{z}$ mniejszych przedsiębiorstw będących własnościa pojedynczych osób lub rodzin. Ich rynki zbytu są ograniczone, a techniki produkcji i marketingu nie tak nowoczesne jak w firmach sektora centralnego ${ }^{16}$.

Przedsiębiorstwa sektora kluczowego sa monopolistyczne lub oligopolistyczne, mają większą siłę rynkową niż konkurencyjne firmy $\mathrm{z}$ sektora peryferyjnego. Inne różnice dotyczą zasobów finansowych, liczby zatrudnionych, zasad organizacyjnych oraz powiązań z rządem.

Podział na sektory ma wpływ na sytuację pracowników, gdyż sektor konkurencyjny charakteryzuja ${ }^{17}$ :

\footnotetext{
15 R. D. Barron, G. M. Norris, op. cit., s.132.

${ }^{16}$ R. F. Averitt, The Dual Economy: The Dynamics of American Industry Structure, W. W. Norton and Company, New York 1968, s. 7.

${ }^{17}$ I. Reszke, Nierówności ptci $w$ teoriach. Teoretyczne wyjaśnienia nierówności ptci w sferze pracy zawodowej, IFIS PAN, Warszawa 1991, s. 108.
} 
1) niskie płace,

2) duże bezrobocie i niedostateczne zatrudnienie,

3) niskie wymagania co do kwalifikacji,

4) minimalne szkolenie na stanowisku pracy.

Sektor centralny odznacza się natomiast:

1) wysokimi płacami;

2) wewnętrznymi rynkami pracy ${ }^{18}$;

3) zorganizowaniem pracowników w związki zawodowe.

Przedsiębiorstwa w sektorze centralnym osiągaja większe zyski. Dzięki temu moga zapewnić pracownikom wyższe płace i lepsze warunki pracy. Poza tym tylko w sektorze centralnym stosuje się nowoczesną technologię wymagająca kwalifikacji specyficznych dla danej firmy, co powoduje konieczność szkoleń na stanowiskach pracy i tworzenia wewnętrznych rynków pracy. Ponadto tylko w firmach centralnych stosuje się techniczną i biurokratyczna kontrolę pracowników, nie tylko ze względu na wielkość przedsiębiorstwa i technologię, lecz także $\mathrm{z}$ powodu organizowania się pracowników w związki zawodowe. Ta biurokratyczna kontrola pracowników ma na celu koordynowanie procesu pracy, sprawowanie władzy oraz stwarzanie podziałów między pracownikami przez tworzenie sztucznych hierarchii i nierówności. W sektorze peryferyjnym technologia nie wymaga natomiast specyficznych kwalifikacji, a kontrola jest osobista i bezpośrednia. W rezultacie powstają dwa rynki pracy: pierwszorzędny w sektorze centralnym i drugorzędny w sektorze peryferyjnym. Pociaga to za sobą określone konsekwencje dla pracowników oraz selekcję do pierwszorzędnego segmentu według cech niezależnych od pracownika ${ }^{19}$.

Nierówności według tej koncepcji wynikają z przypisywania osób z dyskryminowanych grup do sektora peryferyjnego. Determinantami nierówności na rynku pracy w koncepcji dualnej gospodarki sa segmentacja rynku pracy, zasady selekcji kandydatów do pracy oraz interesy pracodawców dotyczące szkoleń pracowników.

\section{TEORIE POKREWNE OPARTE NA SEGMENTACJI RYNKU PRACY}

Wśród teorii pokrewnych opartych na segmentacji rynku pracy odnoszących się do nierówności na tym rynku można zaliczyć teorię peryferyjności D. Morse'a, teorię dyskryminacji na rynku pracy C. Offego i K. Hinrichsa oraz teorię rynku pracy jako areny R. Loveridge'a i A. L. Moka.

${ }^{18}$ Chociaż zewnętrzny rynek pracy wykazuje głównie cechy rynku peryferyjnego, musi istnieć również w sektorze centralnym (np. bramy wejścia do wielkich przedsiębiorstw). Chociaż wewnętrzne rynki pracy przeważaja w sektorze centralnym, muszą znajdować się również w sektorze peryferyjnym (np. w przedsiębiorstwach charakteryzujących się gorszą sytuacją zatrudnieniową dla pracowników) zob. E. Kryńska, Teoria i praktyka segmentacji rynku pracy - część II, s. 38-39.

19 I. Reszke, op. cit., s. 109. 


\section{Teoria peryferyjności D. Morse’a}

D. Morse jest autorem teorii peryferyjności ${ }^{20}$. Teoria ta jest zbliżona do teorii dualnego rynku pracy, choć autor uważa ja za „bardziej realistyczna”" Zdaniem D. Morse'a w ,gorszych” zawodach oraz w ,gorszych” branżach pracuja kategorie demograficzne o niskim statusie. Występuja tu wzajemne oddziaływania. $\mathrm{Z}$ jednej strony zawód lub branża może obniżać status pracowników, a z drugiej - poszczególne kategorie pracownicze mogą obniżać status zawodów lub branż.

Pozycja zawodu lub branży częściowo zależy od ciągłości zatrudnienia. Zawody i branże dające najniższą ciagłość i stałość pracy zatrudniają kategorie demograficzne o najniższym statusie. Niższy status wynika $\mathrm{z}$ socjalizacji $\mathrm{w}$ rodzinie i w szkole. Zaszczepia się pewnym grupom społecznym znacznie słabsze nastawienie na stałą pracę zawodową oraz mniejsze zaangażowanie $\mathrm{w}$ taką pracę i dlatego osoby $\mathrm{z}$ tych grup częściej stają się peryferyjnymi pracownikami. Peryferyjne miejsca pracy według D. Morse’a charakteryzuja się:

1) niskimi płacami,

2) małymi świadczeniami firmy,

3) często zatrudnieniem w niepełnym wymiarze czasu.

i skupiają się głównie w rolnictwie, handlu detalicznym i usługach.

$\mathrm{Z}$ drugiej strony pracownicy peryferyjni to tacy, którzy charakteryzuja się:

1) nieciągłością pracy,

2) podejmowaniem pracy sezonowej i dorywczej,

3) podejmowaniem pracy w niepełnym wymiarze godzin.

Stanowią oni kategorię pracowników, która łatwo zarówno zatrudnić, jak i zwolnić w miarę potrzeb pracodawcy. Duża część takich pracowników zmuszona jest do przyjęcia peryferyjnych miejsc pracy $\mathrm{z}$ braku innych możliwości.

Natomiast nieperyferyjni pracownicy to przede wszystkim zatrudnieni przez cały rok, w pełnym wymiarze czasu. Zatrudniają ich przeważnie firmy zbiurokratyzowane, w których kapitałochłonność jest wysoka. Sa to z reguły firmy o skali krajowej lub międzynarodowej.

Determinantami nierówności na rynku pracy w teorii D. Morse'a są: segmentacja zawodów i branż, socjalizacja oraz role przypisywane dyskryminowanym grupom społecznym, które wpływają na ciągłość zatrudnienia.

\footnotetext{
${ }^{20}$ Teorię peryferyjności przedstawił D. Morse, The Peripheral Worker, Columbia University Press, London 1969.

${ }^{21}$ Teoria D. Morse'a zbliżona jest do teorii dwojakiego rynku pracy Doeringera i Piore'a (którą zresztą poprzedziła w czasie) przez to, że celem jej jest głównie wyjaśnienie sytuacji najbardziej upośledzonych pracowników, lecz różni się od tej teorii wyraźniejszym rozgraniczeniem segmentów rynku pracy i ich zlokalizowaniem. Sciślej określa umiejscowienie drugorzędnych, peryferyjnych pracowników.
} 


\section{Teoria dyskryminacji na rynku pracy C. Offego i K. Hinrichsa}

C. Offe i K. Hinrichs badali ${ }^{22}$ drugorzędny rynek pracy w RFN. Zastanawiali się, dlaczego na tym rynku przeważają członkowie tzw. grup stwarzających problemy, do których zaliczyli kobiety oraz imigrantów, młodzież, starszych pracowników, niepełnosprawnych i przybywających ze wsi. Zdaniem tych autorów korporacje dążą do tego, żeby mieć do dyspozycji masę pracowników z małą siłą oporu, których można z łatwością wyzyskiwać i szantażować. Grupa ta składa się $\mathrm{z}$ pracowników łatwych do zastąpienia i niewymagających większego inwestowania w ich szkolenie.

Siła oporu grup ,,stwarzających problemy” jest mniejsza niż wykwalifikowanych pracowników, ale także niż niewykwalifikowanych miejscowych mężczyzn. Jest to uwarunkowane tym, że:

1) istnieją dla tych grup alternatywne role poza rynkiem pracy dające źródło utrzymania,

2) polityka prowadzona przez związki zawodowe ogranicza siłę oporu tych grup pracowniczych.

Chociaż alternatywne role poza rynkiem pracy sa z reguły gorsze, to są one częściowo akceptowane przez samych marginalnych pracowników. Może to przyczyniać się do niewielkiej identyfikacji z wykonywana praca i małego udziału w związkach zawodowych. Polityka związków zawodowych w zakładach pracy kieruje się głównie wyobrażeniem „normalnego” pracownika, pracującego $\mathrm{w}$ pełnym wymiarze czasu, któremu nie przypisuje się żadnych alternatywnych ról ekonomicznych. W rezultacie członkowie grup „stwarzających problemy" ${ }^{23}$ nie mają indywidualnej siły przetargowej na ryku pracy ani nie mają również skutecznie działającej reprezentacji swoich zbiorowych interesów.

Czynnikami powodującymi względne upośledzenie osób z grup dyskryminowanych na rynku pracy (i to zarówno niewykwalifikowanych i ,,marginalnych”, jak i wysoko wykwalifikowanych oraz pracujących w pełnym wymiarze czasu) jest brak dostatecznego poparcia związków zawodowych, przekonanie o istnieniu alternatywnych źródeł utrzymania dla grup dyskryminowanych oraz przypisywane im role społeczne.

\footnotetext{
${ }^{22}$ Swoją teorię przedstawili w C. Offe, K. Hinrichs, Sozialökonomie des Arbeitmarktes und die Lage „,benachteiligter” Gruppen von Arbeitnehmern, w: C. Offe, Opfer des Arbeitmarktes zur Theorie der strukturierten Arbeitslosigkeit, Neuwied, Darmstadt 1977.

${ }^{23}$ R. Krekel proponuje następującą hierarchiczną typologię pracowników drugorzędnego sektora rynku pracy: 1) na dole hierarchii znajdują się nielegalni imigranci niemający możliwości jawnej obrony swoich interesów; 2) nad nimi są różne grupy pracowników marginalnych lub napiętnowanych, niewykwalifikowanych i takich, którzy ulegli dekwalifikacji i którzy uzyskują bardzo małe solidarnościowe poparcie ze strony związków zawodowych. Łączy ich brak liczącej się siły przetargowej, ale sa podzieleni przez czynniki przypisane, takie jak płeć, wiek, rasa i pochodzenie etniczne. Takie wewnętrzne podziały hamują rozwój zorganizowanej solidarności, która mogłaby być jedynym źródłem znacznej siły przetargowej w tym sektorze rynku pracy - por. R. Krekel, Unequal Opportunity Structure and Labour Market Segmentation, ,,Sociology” 1980, nr 4 (14), s. 525-555.
} 


\section{Teoria rynku pracy jako areny R. Loveridge'a i A. L. Moka}

R. Loveridge i A. L Mok przedstawili teorię rynku pracy jako areny ${ }^{24}$ w 1979 r. Autorzy analizuja sytuację na rynkach pracy w państwach Europy Zachodniej. Według nich rynki te charakteryzuja się:

1) zmniejszaniem się proporcji pracujących $w$ relacji do niepracujących,

2) wysokim i długotrwałym bezrobociem,

3) występowaniem marginalnych pracowników.

Bezrobocie jest częstsze wśród kobiet, imigrantów, osób starszych i innych upośledzonych kategorii. Marginalni pracownicy z reguły nie mają tożsamości zawodowej lub jest ona bardzo słaba. Marginalne zawody charakteryzuje natomiast nieokreśloność i niepewność statusu. Czynności wykonywane w tych zawodach sa monotonne i brudne, dają małe szanse wykorzystania kwalifikacji i możliwości pracownika.

Upośledzenie grup dyskryminowanych na rynku pracy autorzy wyjaśniaja małymi możliwościami zorganizowania się w grupę nacisku. Przyczynami takiego stanu rzeczy sa:

1) rozproszenie,

2) brak tożsamości zawodowej ${ }^{25}$,

3) brak świadomości interesów zbiorowych,

4) postawy i wartości niesprzyjające stałości i ciągłości pracy.

Teoria ta wskazuje na grupowe protesty, które powodują zmiany w działaniu rynku pracy. Protesty te często wyrażają wolę wprowadzania w życie uprawnień, które nie były w ogóle prawnie regulowane lub były regulowane, lecz nie były realizowane i przestrzegane. Takie akcje zmieniaja sytuacje kategorii upośledzonych na rynku pracy. R. Loveridge i A. L. Mok rozpatruja możliwości ich organizowania się i wykorzystywania przez nich ustawodawstwa zwalczającego ich upośledzenie na rynku pracy. Autorzy twierdzą również, że bez współdziałania samych zainteresowanych aktywność legislacyjna i opiekuńcza państwa nie może być skuteczna.

Struktura rynku pracy jest więc konsekwencją działających sił polityczno-gospodarczych. Autorzy twierdza, że obecnie wolną konkurencję zastąpiły zmonopolizowane przetargi między związkami zawodowymi a pracodawcami. Konflikty istnieja nadal, lecz znajduja wyraz $\mathrm{w}$ formach biurokratycznie prawomocnych.

${ }^{24}$ Swoją teorię przedstawili w R. Loveridge, A. L. Mok, op. cit., s. 173-185.

${ }^{25}$ R. Loveridge i A. L. Mok proponują następujący podział upośledzonych społecznie pracowników według kryterium strategicznej tożsamości: 1) indywidualnie upośledzeni przez osobistą sytuację i niemający żadnego wpływu na działanie rynku pracy, np. niektóre kategorie inwalidów; 2) zbiorowo upośledzeni, postrzegający swoją sytuację jako indywidualną i nieświadomi środków poprawy tej sytuacji. Nie sa oni zdolni do wyobrażenia sobie legalnych sposobów poprawy swojej sytuacji. Ich zachowania determinuje głównie bezpośrednia konieczność zdobycia środków utrzymania; 3) zbiorowo upośledzeni, mający świadomość swego istnienia jako „ekonomicznej społeczności”, czyli grupy świadomej istnienia publicznego lub wspólnego dobra, z którego korzystania żaden członek grupy nie może być wykluczony; 4) zbiorowo upośledzeni, którzy uświadomili sobie swoje istnienie jako grupy nacisku i są świadomi prawnych i administracyjnych sposobów osiągania publicznego lub wspólnego dobra. Odnosi się to do członków związków zawodowych oraz innych stowarzyszeń. Zob. R. Loveridge, A. L. Mok, op. cit., s. 180. 
Teoria rynku pracy jako areny bierze pod uwagę wpływ ruchów społecznych na sytuację kategorii upośledzonych na rynku pracy. Zakłada również, że jedyną drogą wyjścia z sytuacji kategorii społecznie upośledzonych jest ich zorganizowany opór. Determinantami nierówności są rozproszenie, niska tożsamość zawodowa, brak uczestnictwa w związkach zawodowych i brak solidarnościowego poparcia tych związkó ${ }^{26}$ oraz postawy i wartości osób z grup dyskryminowanych na rynku pracy niesprzyjające stałości i ciągłości pracy.

\section{ZAKOŃCZENIE}

Wyjaśnienia nierówności na rynku pracy i jej determinanty podawane $\mathrm{w}$ teoriach przyjmujących założenia segmentacji rynku pracy nie sa wystarczające, ale mogą uzupełniać wyjaśnienia zawarte $\mathrm{w}$ innych teoriach, gdyż wskazują, że osoby z grup dyskryminowanych poszukujące pracy nie są traktowane indywidualnie, lecz podlegaja statystycznej dyskryminacji i że segregacja zawodowa prowadzi do relatywnego upośledzenia tych osób w zarobkach. Wspólne dla wszystkich wariantów teorii segmentacji rynku pracy jest wyjaśnianie nierówności społecznych przez nierówny dostęp poszczególnych kategorii pracowników do bardziej nagradzających miejsc pracy. Część miejsc pracy dających większe korzyści jest ograniczona i przypada w udziale określonym kategoriom społecznym i jednocześnie staje się źródłem względnego uprzywilejowania jednych i relatywnego upośledzenia innych.

Determinantami nierówności w sferze pracy zawodowej w tych hipotezach sa:

- w teorii segmentacji statystycznej: segmentacja rynku pracy według wyróżników charakterystycznych dla poszczególnych grup społecznych, przypisywanie poszczególnym grupom społecznym określonych cech i zasady selekcji pracowników do pracy;

- w koncepcji rynków wewnętrznych i zewnętrznych: segmentacja rynku pracy (podział na rynki wewnętrzne i zewnętrzne), zasady selekcji kandydatów do pracy, interesy pracodawców dotyczące szkoleń pracowników, nieciągłość zatrudnienia przypisywana określonym grupom społecznym, różne role społeczne przypisywane grupom społecznym;

- w koncepcji dualnego rynku pracy: segmentacja rynku pracy (podział na rynek pierwszorzędny i drugorzędny), zasady selekcji kandydatów do pracy, interesy pracodawców dotyczące szkoleń pracowników, faktyczne lub pozorne role społeczne i związana z tym nieciągłość zatrudnienia przypisywane różnym grupom społecznym, złe nawyki nabierane przez pracowników zatrudnionych w drugorzędnych miejscach pracy;

- w koncepcji dualnej gospodarki: segmentacja rynku pracy (podział na sektor centralny i peryferyjny), zasady selekcji kandydatów do pracy, interesy pracodawców dotyczące szkoleń pracowników;

- w teorii peryferyjności D. Morse'a: segmentacja zawodów i branż (podział na peryferyjne i nieperyferyjne zawody i branże oraz peryferyjnych

${ }^{26}$ I. Reszke, op. cit., s. 121. 
i nieperyferyjnych pracowników), socjalizacja, role przypisywane dyskryminowanym grupom społecznym;

- w teorii dyskryminacji na rynku pracy C. Offego i K. Hinrichsa: brak dostatecznego poparcia związków zawodowych, przekonanie o istnieniu alternatywnych źródeł utrzymania dla grup dyskryminowanych, przypisywane im role społeczne;

- w teorii rynku pracy jako areny R. Loveridge'a i A. L. Moka: rozproszenie, niska tożsamość zawodowa, postawy i wartości niesprzyjające stałości i ciągłości pracy, brak uczestnictwa w związkach zawodowych i brak poparcia związków zawodowych.

dr Patrycja Zwiech

Uniwersytet Szczeciński

patrycjazwiech@tlen.pl

\section{SOCIO-ECONOMIC INEQUALITIES IN THE CONTEXT \\ OF LABOUR MARKET SEGMENTATION THEORY}

\section{Summary}

This paper describes theories that attempt to explain the existence of economic inequalities among social groups in the labour market in the context of the doctrine of market segmentation. The determinants of these inequalities are also presented. The paper focuses on the following issues: statistical segmentation, the concept of the internal and external market, the concept of the dual labour market, the theory of dual economy, the peripherality theory, the theory of discrimination on the labour market and the concept of labour market as an arena. The determinants of inequalities resulting from these theories are as follows: labour market segmentation according to the features specific to various social groups or according to the characteristics of the labour market, the rules for the selection of employees, employers' interests regarding the training of employees, insufficient support of trade unions, socialisation, assigning to each social group actual or apparent qualities or social roles, bad habits gained by secondary workers, employment discontinuity, low professional identity, dissipation, attitudes and values inimical to stability and continuity. 
Copyright of Journal of Law, Economics and Sociology is the property of Faculty of Law and Administration of Adam Mickiewicz University in Poznan and its content may not be copied or emailed to multiple sites or posted to a listserv without the copyright holder's express written permission. However, users may print, download, or email articles for individual use.

Właścicielem praw autorskich do „Ruchu Prawniczego, Ekonomicznego i Socjologicznego” jest Wydział Prawa i Administracji Uniwersytetu im. Adama Mickiewicza w Poznaniu. Zawartość czasopisma nie może być kopiowana, przesyłana do innych stron internetowych bądź zamieszczana na blogach bez pisemnej zgody wydawcy. Niemniej artykuły można drukować, kopiować lub przesyłać w formie elektronicznej na własny użytek. 